\title{
Traditional Chinese medicine formulation Yanggan Jiedu Sanjie inhibits TGF- $\beta 1$ - induced epithelial-mesenchymal transition and metastatic potential in human hepatocarcinoma Bel-7402 cells
}

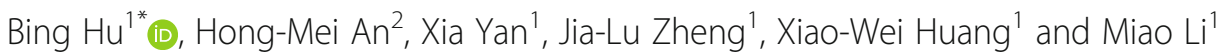

\begin{abstract}
Background: Epithelial-mesenchymal transition (EMT) is a vital process in cancer progression and metastasis. Yanggan Jiedu Sanjie (YGJDSJ) is Traditional Chinese Medicine formulation for liver cancer treatment. In the present study, we evaluated the effects of YGJDSJ on TGF- $\beta 1$-induced EMT in hepatocellular carcinoma Bel-7402 cells.

Methods: Bel-7402 cells were treated with TGF- $\beta 1$ and YGJDSJ. EMT was identified by morphological changes and expression of marker proteins. Cell morphology was observed under a microscope. Protein expression and phosphorylation was detected by western blotting. Cell migration was measured by the scratch assay. Cell adhesion and invasion was detected by a commercial kit.

Results: YGJDSJ reversed TGF- $\beta 1$-induced morphological changes, as well as the expression of the EMT markers Ecadherin and N-cadherin in Bel-7402 cells. YGJDSJ also inhibited TGF- $\beta 1$ up-regulated Smad3 phosphorylation and Snail expression in Bel-7402 cells. Moreover, YGJDSJ inhibited TGF- $\beta 1$-induced cell adhesion, migration and invasion in Bel-7402 cells.
\end{abstract}

Conclusions: YGJDSJ inhibited TGF- $\beta 1$-induced EMT and mediated metastatic potential of Bel-7402 cells, which may be related to down-regulation of Smad3 phosphorylation and Snail expression. The present study provides a new basis for application of this herbal formula for prevention of liver cancer metastasis.

Keywords: Hepatocellular carcinoma, Epithelial-mesenchymal transition, Chinese herbal medicine, Metastasis

\section{Background}

Liver cancer ranks sixth in incidence and fourth in mortality among all cancers globally [1]. Hepatocellular carcinoma (HCC) is the most common liver cancer (7585\%) [1]. Surgery is the only curative treatment option for early HCC $[2,3]$. HCC is prone to metastasize to lung (39.5-53.8\%), lymph node (33.8-34.2\%), bone (25.4-38.5\%) and other sites through the lymph or blood circulation $[4,5]$. The efficacy of current treatment for

\footnotetext{
* Correspondence: beearhu@hotmail.com

${ }^{1}$ Institute of Traditional Chinese Medicine in Oncology, Department of Oncology, Longhua Hospital, Shanghai University of Traditional Chinese Medicine, Shanghai 200032, People's Republic of China

Full list of author information is available at the end of the article
}

metastatic HCC, including radiotherapy, chemotherapy and targeted therapy, is very poor [6, 7]. Therefore, prevention of HCC metastasis is particularly important.

HCC metastasis is closely related to epithelial-mesenchymal transition (EMT) [8, 9]. EMT is a biological process in which epithelial cells lose their epithelial characteristics and acquire the phenotype of mesenchymal cells, including changes in cell morphology and expression of marker proteins, such as down-regulation of epithelial marker gene E-cadherin and up-regulation of mesenchymal marker gene N-cadherin [8,9]. Tumor cells with EMT have increased motility and invasiveness, which facilitate their metastasis. Suppression of EMT could inhibit HCC metastasis [10, 11]. 
Yanggan Jiedu Sanjie (YGJDSJ) is a modern Chinese herbal formula developed by us for the treatment of HCC [12]. YGJDSJ composed of multiple herbs. Some herbs in YGJDSJ have demonstrated inhibitory effects on EMT in cancer cells. Solanum nigrum L. (Long-Kui) and its ingredient $\alpha$-Solanine, polysaccharide of Scutellaria barbata D. Don (Ban-Zhi-Lian), Duchesnea indica (Andr.) Focke (She-Mei), and $\beta$-elemene (a compound of Curcuma wenyujin Y.H. Chen et C. Ling (Yü-Jin)) can inhibit EMT in various cancer cells [13-17]. These findings suggested that YGJDSJ may also have a similar effect on EMT. In this study, we evaluated the effect of YGJDSJ on transforming growth factor- $\beta 1$ (TGF- $\beta 1$ )-induced EMT in human HCC Bel-7402 cells.

\section{Materials and methods}

\section{Chemicals and reagents}

DMEM medium and fetal bovine serum were purchased from Thermo Fisher Scientific (Waltham, MA). TGF- $\beta 1$ was obtained from PeproTech (Rocky Hill, NJ). Antibodies against Smad3, p-Smad3 (Ser423/425), Snail and GAPDH were from Cell Signaling Technology (Danvers, MA). E-cadherin and N-cadherin antibodies were bought from Santa Cruz Biotechnology (Santa Cruz, CA). CytoSelect ${ }^{\mathrm{TM}}$ 48-Well Cell Adhesion Assay and CytoSelect $^{\mathrm{Tm}}$ 24-Well Cell Invasion Assay kits were produced by Cell Biolabs (San Diego, CA).

\section{YGJDSJ extraction}

The herbs in YGJDSJ formula (Chinese patent No. ZL201110145109.0) are the fruits of Ligustrum lucidum Ait. (Nü-zhen-zi) $12 \mathrm{~g}$, D. indica (Andr.) Focke (SheMei) 15 g, S. nigrum L. (Long-Kui) 15 g, S. barbata D. Don (Ban-Zhi-Lian) $30 \mathrm{~g}$, Euphorbia helioscopia L. (Ze-Qi) $15 \mathrm{~g}$, the root of Ranunculus ternatus Thunb. (Mao-Zhua-Cao) $15 \mathrm{~g}$, the root of $C$. wenyujin $\mathrm{Y}$. $\mathrm{H}$. Chen et C. Ling (Yü-Jin) $15 \mathrm{~g}$ and the root of Polygonum cuspidatum Sieb. et Zucc. (Hu-Zhang) 15 g. All herbs were obtained from the dispensary of Chinese medicine of Longhua Hospital and identified by Professor Liwen $\mathrm{Xu}$ from Shanghai University of Traditional Chinese Medicine, Shanghai, China. Voucher specimen is deposited in Institute of Traditional Chinese Medicine in Oncology, Longhua Hospital, Shanghai University of Traditional Chinese Medicine, Shanghai, China (specimen number: TCM-HCC-001). YGJDSJ extraction has been described previously [12]. YGJDSJ extract were dissolved in PBS and stored at $-20{ }^{\circ} \mathrm{C}$ until further use.

\section{Cell culture}

Bel-7402 cells were obtained from The Cell Bank of Type Culture Collection of Chinese Academy of Sciences (CBTCCCAS) and checked by CBTCCCAS. The cells were cultured in DMEM medium containing $10 \%$
FBS and $1 \%$ Pen-Strep, and maintained at $37^{\circ} \mathrm{C}$ in a humidified atmosphere with $5 \% \mathrm{CO}_{2}$.

\section{EMT induction}

Bel-7402 cells $\left(5 \times 10^{5}\right)$ in logarithmic growth phase were inoculated in 6-well plates and cultured in serum free DMEM and allowed to attach for $24 \mathrm{~h}$ before treatment. The cells were then treated with TGF- $\beta 1$ (10 ng/ $\mathrm{mL})$ and YGJDSJ $(100 \mu \mathrm{g} / \mathrm{mL})$ or same volume of PBS for $48 \mathrm{~h}$. The morphology of the cells was observed under a microscope.

\section{Scratch / migration assay}

Cell migration was measured by the scratch assay $[18,19]$. Bel-7402 cells $\left(1 \times 10^{6}\right)$ were incubated in 6-well plates and cultured to $95 \%$ confluency. Then the cells were scratched by a sterile pipette tip, and washed three times with PBS. Fresh medium was added and the cells were treated with TGF- $\beta 1(10 \mathrm{ng} / \mathrm{mL})$ and YGJDSJ $(100 \mu \mathrm{g} / \mathrm{mL})$ or equal volume of PBS for $48 \mathrm{~h}$. The cell migration was observed by microscopy.

\section{Cell adhesion assay}

Cell adhesion was detected by a commercial kit according to the manufacturer's manual. Briefly, $1 \times 10^{5}$ TGF- $\beta 1$ and YGIDSJ treated or untreated Bel-7402 cells were added to a 48 well plate. TGF- $\beta 1(10 \mathrm{ng} / \mathrm{mL})$, YGJDSJ $(100 \mu \mathrm{g} / \mathrm{mL})$ or same volume of PBS was also added to the wells. Cells were incubated for $90 \mathrm{~min}$ at $37^{\circ} \mathrm{C}$ and stained with staining solution for $10 \mathrm{~min}$ at room temperature. After aspirating the staining solution, the plate was gently washed three times with $500 \mu \mathrm{lde}$ ionized water and air dried. $200 \mu \mathrm{L}$ of extraction solution was then added to the wells and incubated for $10 \mathrm{~min}$. The optical density of each well was measured at OD $560 \mathrm{~nm}$ by a plate reader.

\section{Cell invasion assay}

Cell invasion was detected by a commercial kit according to the manufacturer's protocol. Briefly, $3 \times 10^{5}$ TGF- $\beta 1$ and YGJDSJ treated or untreated Bel-7402 cells were added to the inner side of cell insert, and $500 \mu \mathrm{L}$ of DMEM media with $10 \%$ FBS was added to the lower well of the invasion plate. TGF- $\beta 1(10 \mathrm{ng} / \mathrm{mL})$, YGJDSJ $(100 \mu \mathrm{g} / \mathrm{mL})$ or same volume of PBS was also added to the wells. The cells were incubated for $12 \mathrm{~h}$ at $37^{\circ} \mathrm{C}$. After removing the non-invasive cells, the inserts were stained with staining solution for $10 \mathrm{~min}$ at room temperature, and observed under a microscope. $200 \mu \mathrm{L}$ of extraction solution was then added to the wells and incubated for $10 \mathrm{~min}$. The optical density of each well was measured at OD $560 \mathrm{~nm}$ by a plate reader. 


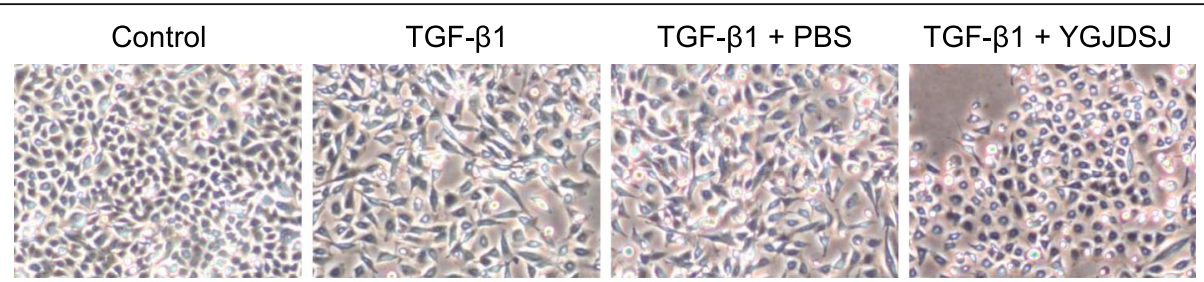

Fig. 1 Effects of YGJDSJ on TGF- $\beta 1$-induced morphological changes. Bel-7402 cells were treated with TGF- $\beta 1$ and YGJDSJ or PBS for 48 h, and cell morphology was observed under a microscope $(\times 200)$

\section{Western blot}

Western blotting was performed as previously described $[20,21]$. Briefly, the cells were lysed and subjected to $8-$ $12 \%$ SDS-PAGE electrophoresis, and then transferred onto a nitrocellulose membrane (Bio-Rad, Richmond, CA). The membrane was blocked with $5 \%$ non-fat milk, washed, and probed with antibodies against E-cadherin (1:200), N-cadherin (1:200), Smad3 (1:1000), p-Smad3 (1:1000), Snail $(1: 1000)$ or GAPDH $(1: 2000)$ at $4{ }^{\circ} \mathrm{C}$ overnight. The blots were then washed and incubated with secondary antibodies (1:4000), developed by ECL substrates and exposed by ChemiDoc ${ }^{\mathrm{Tm}}$ Touch Imaging System (Bio-Rad, Hercules, CA). Proteins expression was quantified by the Quantity One software (Bio-Rad, Hercules, CA).

\section{Statistical analyses}

Results are expressed as means \pm standard deviation of at least two independent experiments. Differences between different treatment groups were analyzed by one-way ANOVA. Differences were considered significant at $p$-values $<0.05$.

\section{Results}

YGJDSJ reversed TGF- $\beta 1$-induced morphological changes After TGF- $\beta 1$ treatment, the morphology of Bel-7402 cells changed from round or oval to spindle shaped. The distribution of the cells was looser and they exhibited mesenchymal morphology. After YGJDSJ treatment, Bel-7402 cells were reverted to epithelial morphology, which was round or oval (Fig. 1).

\section{YGJDSJ reversed TGF- $\beta 1$-induced expression change of EMT marker proteins}

Western blot analysis showed that the expression of epithelial marker gene E-cadherin was down-regulated, while the mesenchymal marker gene $\mathrm{N}$-cadherin was up-regulated after TGF- $\beta 1$ treatment. YGJDSJ increased E-cadherin expression and inhibited N-cadherin expression $(p<0.01)$ (Fig. 2). These observations suggested that YGJDSJ inhibited TGF- $\beta 1$-induced EMT in Bel-7402 cells.

YGJDSJ inhibited TGF- $\beta 1$-induced Smad3 phosphorylation It has been reported that Smad3 is involved in TGF- $\beta 1$ induced EMT [22, 23]. We observed Smad3 expression and phosphorylation by western blot. The results showed that the expression of Smad3 did not change significantly; but the phosphorylation levels of Smad3 were increased after TGF- $\beta 1$ treatment. YGJDSJ could inhibit TGF- $\beta 1$-induced phosphorylation of Smad3 ( $p<$ 0.01) (Fig. 3).

\section{YGJDSJ inhibited TGF- $\beta 1$-induced Snail expression}

Snail is an important transcriptional regulator of EMT that can be up-regulated by TGF- $\beta 1[24,25]$.
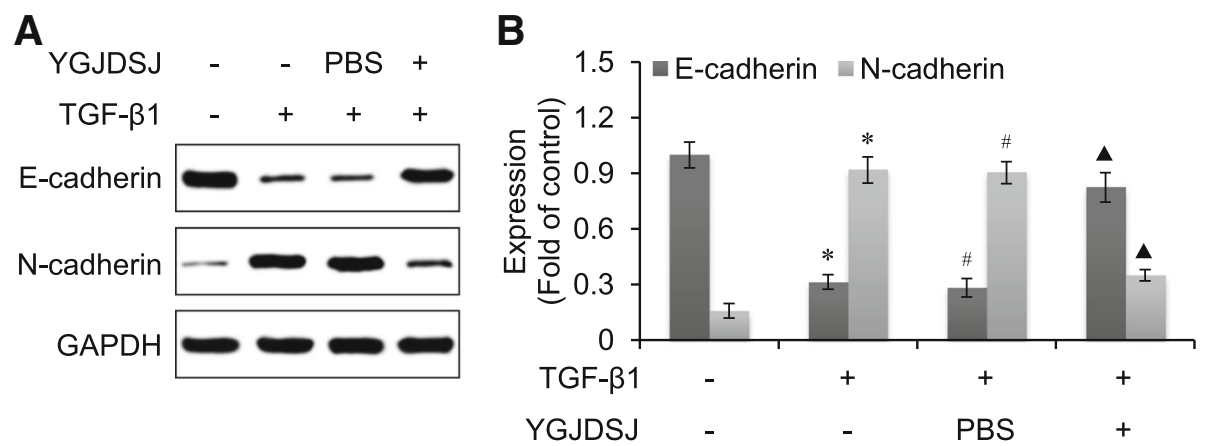

Fig. 2 Effects of YGJDSJ on TGF- $\beta 1$-induced expression change of EMT marker proteins. $\mathbf{a}$, Bel-7402 cells were treated with TGF- $\beta 1$ and YGJDSJ or PBS for $48 \mathrm{~h}$, and subjected to western blotting using indicated antibodies. $\mathbf{b}$, protein expression was quantified by the Quantity One software. ${ }^{*} p$ $<0.01$, versus control group; ${ }^{\#} p>0.05$, versus TGF- $\beta 1$ group; $p<0.01$, versus PBS group 

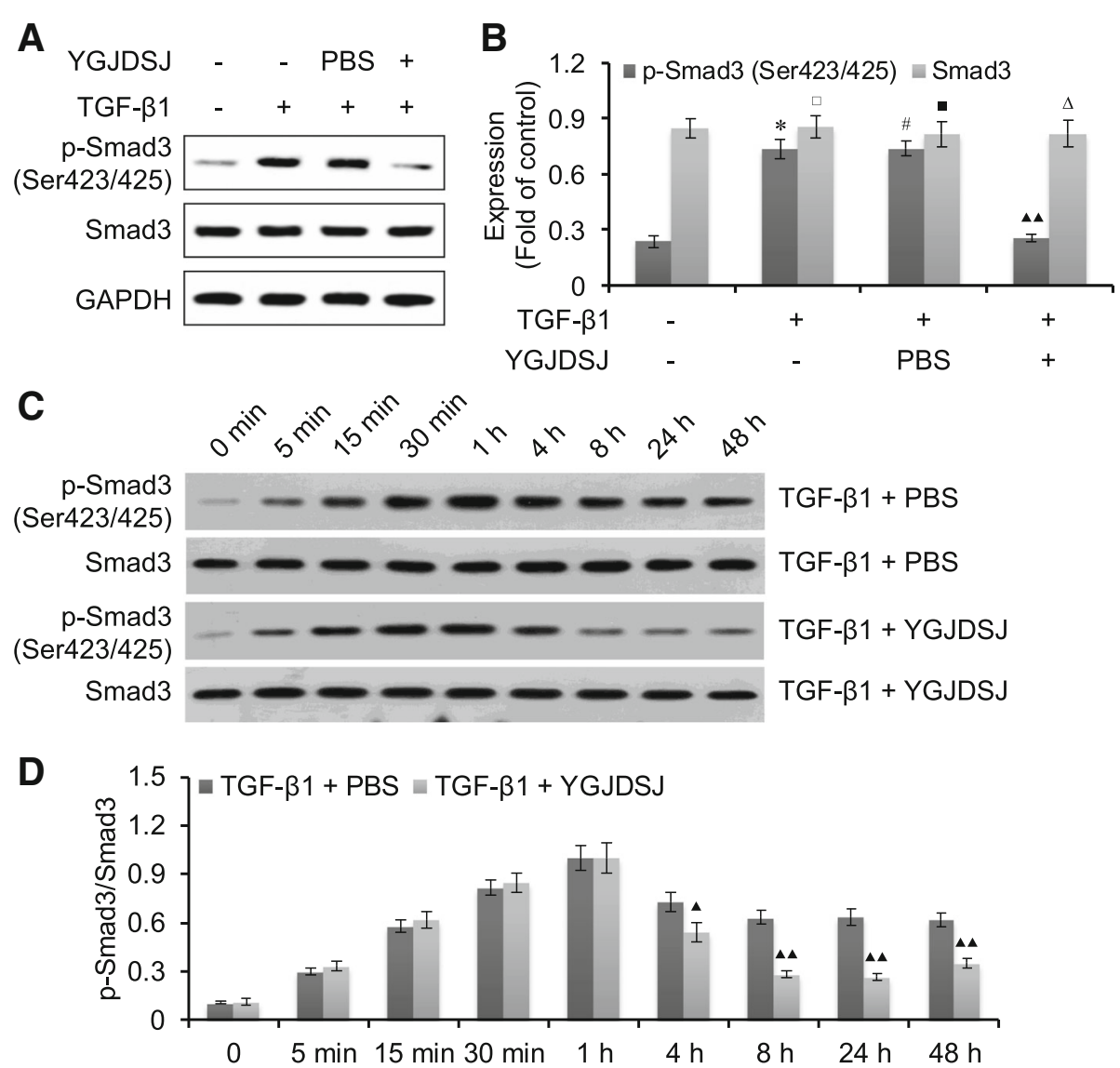

Fig. 3 Effects of YGJDSJ on TGF- $\beta 1$-induced Smad3 phosphorylation. a, Bel-7402 cells were treated with TGF- $\beta 1$ and YGJDSJ or PBS for $48 \mathrm{~h}$, and subjected to western blotting using indicated antibodies. c, Bel-7402 cells were treated with TGF- $\beta 1$ and YGJDSJ or PBS for indicated times, and subjected to western blotting using Samd3 and p-Smad3. b and $\mathbf{d}$, protein expression was quantified by the Quantity One software. ${ }^{*} p<0.01$, versus control group; ${ }^{p} p>0.05$, versus TGF- $\beta 1$ group; $p<0.05$, versus PBS group; ${ }^{\boldsymbol{\Delta}} p<0.01$, versus PBS group; ${ }^{\square} p>0.05$, versus control group; - $p>0.05$, versus TGF- $\beta 1$ group; ${ }^{\Delta} p>0.05$, versus PBS group

We also detected the expression of Snail. The results showed that the expression of Snail in Bel-7402 cells was up-regulated by TGF- $\beta 1$. YGJDSJ could inhibit the expression of Snail induced by TGF- $\beta 1(p<0.01)$ (Fig. 4).

\section{YGJDSJ inhibited TGF- $\beta 1$-induced cell adhesion}

Cell adhesion is an important biological process in tumor metastasis, and EMT can promote tumor cell adhesion $[26,27]$. The results showed that the adhesion ability of Bel-7402 cells was enhanced by TGF- $\beta 1$.

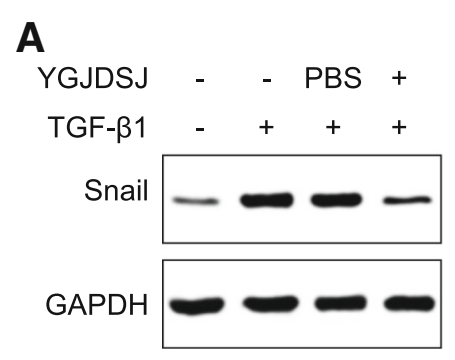

\section{B}

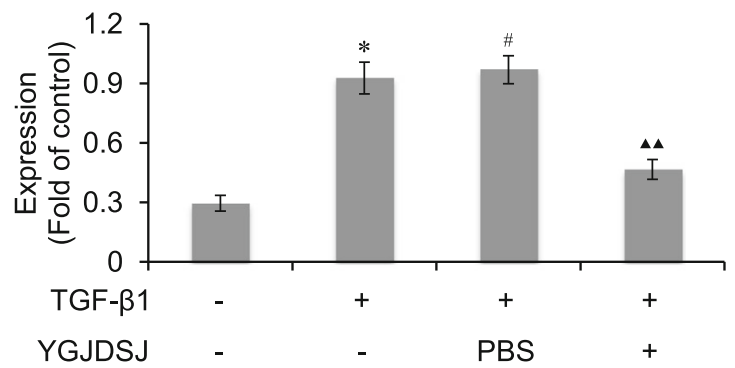

Fig. 4 Effects of YGJDSJ on TGF- $\beta 1$-induced Snail expression. a, Bel-7402 cells were treated with TGF- $\beta 1$ and YGJDSJ or PBS for $48 \mathrm{~h}$, and subjected to western blotting using indicated antibodies. $\mathbf{b}$, protein expression was quantified by the Quantity One software. ${ }^{*} p<0.01$, versus control group; ${ }^{\#} p>0.05$, versus TGF- $\beta 1$ group; $\boldsymbol{\Delta}^{\Delta} p<0.01$, versus PBS group 


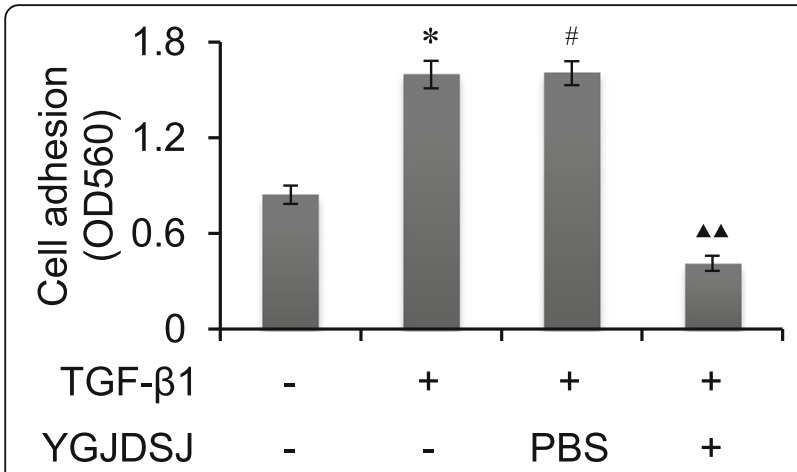

Fig. 5 Effects of YGJDSJ on TGF- $\beta 1$-induced cell adhesion. Bel-7402 cells were treated with TGF- $\beta 1$ and YGJDSJ or PBS for $48 \mathrm{~h}$, and subjected to cell adhesion assay using a commercial kit according to the manufacturer's manual. ${ }^{*} p<0.01$, versus control group; ${ }^{\#} p>0.05$, versus TGF- $\beta 1$ group; ${ }^{\mathbf{\Delta}} p<0.01$, versus PBS group

YGJDSJ could inhibit TGF- $\beta 1$-induced cell adhesion in Bel-7402 cells $(\mathrm{p}<0.01)$ (Fig. 5).

\section{YGJDSJ inhibited TGF- $\beta 1$-induced cell migration}

Scratch assay is a simple and convenient method to detect cell migration $[18,19]$. Results from scratch assay showed that the migration ability of Bel-7402 cells was enhanced by TGF- $\beta 1$; but YGJDSJ inhibited the cell migration induced by TGF- $\beta 1$ (Fig. 6).

\section{YGJDSJ inhibited TGF- $\beta 1$-induced cell invasion}

Cell invasion is an important process in tumor metastasis, and EMT can promote the invasion of tumor cells $[28,29]$. Transwell assay showed that the invasion ability of Bel-7402 cells was enhanced by TGF- 31 . YGJDSJ could inhibit the invasion of Bel-7402 cells induced by TGF- $\beta 1(p<0.01)$ (Fig. 7).

\section{Discussion}

YGJDSJ is composed of several Chinese herbs with anticancer effects. The fruits of L. lucidum Ait. (Nü-Zhen- $\mathrm{Zi}$ ) inhibits proliferation, as well as promotes apoptosis and senescence in HCC cells [30]. S. barbata D. Don (Ban-Zhi-Lian) promotes apoptosis of HCC cells via mitochondrial pathway [31]. S. nigrum L. inhibits proliferation, induces apoptosis, and arrests cell cycle at G2/M phase in HCC cells [32]. D. indica (Andr.) Focke (She-Mei) inhibits proliferation, induces apoptosis, and arrests cell cycle in cervical cancer cells [33].

E. helioscopia L. (Ze-Qi) inhibits tumor growth, induces apoptosis, and inhibits metastasis in HCC [34]. $R$. ternatus Thunb. (Mao-Zhao-Cao) inhibits proliferation and tumor growth in $\mathrm{HCC}[35,36]$. C. wenyujin Y.H. Chen et C. Ling (Yü-Jin) has a wide range of anticancer effects, its main components include $\beta$-elemene and curcumin [37-39]. P. cuspidatum Sieb. et Zucc (Hu-Zhang) exhibits anticancer effect on various tumors and resveratrol is one of its important ingredients [39, 40]. Thus, YGJDSJ is a modern anticancer herbal formula.

Some herbs or compounds in YGJDSJ have showed inhibitory effects on EMT. S. barbata (Ban-Zhi-Lian) polysaccharide inhibits EMT in colon cancer cells [15]. D. indica (She-Mei) extract inhibits migration and EMT in lung adenocarcinoma cells [16]. S. nigrum (Long-Kui) suppresses EMT in breast cancer cells [13]. $\beta$-elemene, a compound from C. wenyujin Y.H. Chen et C. Ling (Yü-Jin), inhibits EMT in glioblastoma and breast cancer cells $[17,41]$. Resveratrol, a component of $P$. cuspidatum Sieb. et Zucc. (Hu-Zhang), inhibits EMT in multiple cancer cells [42-44].

TGF- $\beta 1$ is a cytokine that is associated with multiple bioprocess, such as cell proliferation, differentiation, death and EMT, and is frequently used for EMT induction $[8,22,23,27,42]$. In present study, we observed that upon TGF- $\beta 1$ treatment, the morphology of

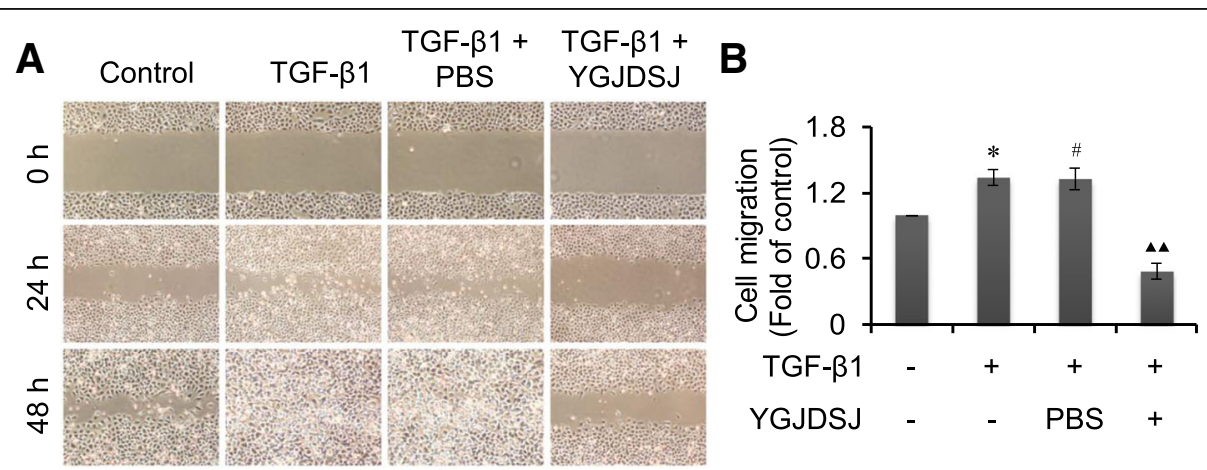

Fig. 6 Effects of YGJDSJ on TGF- $\beta 1$-induced cell migration. a, Bel-7402 cells were scratched by a sterile pipette tip and treated with TGF- $\beta 1$ and YGJDSJ or PBS for $48 \mathrm{~h}$, cell migration was observed under a microscope $(\times 40)$. b. Cell migration distance at $24 \mathrm{~h}$ were measured by electronic ruler and expressed as fold of control. ${ }^{*} p<0.01$, versus control group; ${ }^{\#} p>0.05$, versus TGF- $\beta 1$ group; ${ }^{\boldsymbol{\Delta}} p<0.01$, versus PBS group 

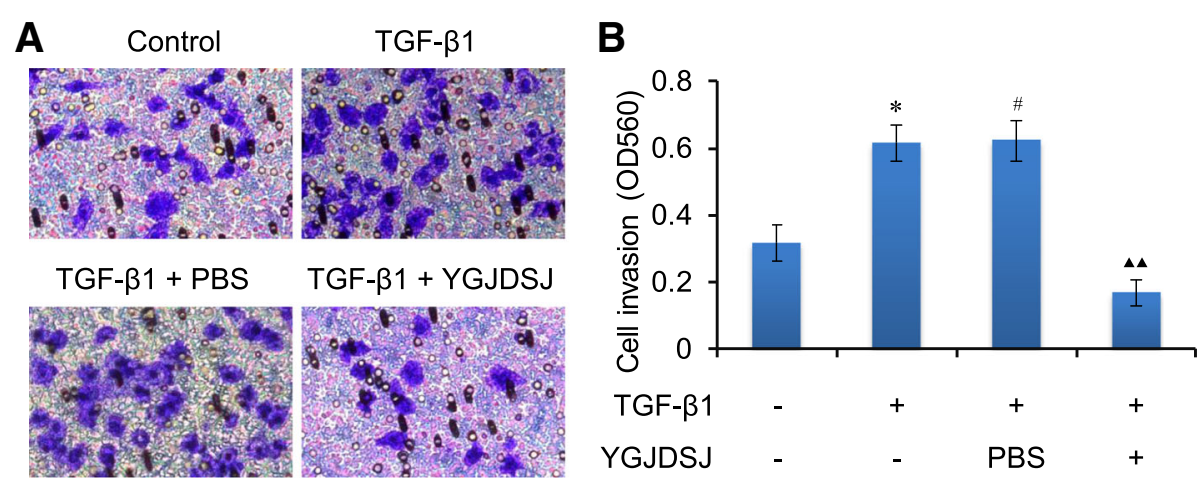

Fig. 7 Effects of YGJDSJ on TGF- $\beta 1$-induced cell invasion. Bel-7402 cells were treated with TGF- $\beta 1$ and YGJDSJ or PBS for 48 h, and subjected to cell invasion assay using a commercial kit according to the manufacturer's protocol. Cell invasion was observed under a microscope $(\times 200)(\mathbf{a})$ and measured at OD $560 \mathrm{~nm}$ by a plate reader (b). ${ }^{*} p<0.01$, versus control group; ${ }^{\#} p>0.05$, versus TGF- $\beta 1$ group; ${ }^{\boldsymbol{\Delta}} p<0.01$, versus PBS group

Bel-7402 cells changed from oval epithelial morphology to spindle mesenchymal morphology with down-regulation of E-cadherin and up-regulation of $\mathrm{N}$-cadherin, indicating the occurrence of EMT. On the other hand, YGJDSJ reversed TGF- $\beta 1$-induced morphological changes, as well as the expression of the EMT markers E-cadherin and N-cadherin in Bel-7402 cells, suggesting that YGJDSJ could inhibit EMT induced by TGF- $\beta 1$.

TGF- $\beta 1$ binding to its receptor could recruit and phosphorylate Smads, and up-regulate Snail, thus leading to EMT $[8,45-47]$. Snail is an EMT-related transcriptional repressor, which regulate the transcription of target genes, such as E-cadherin, and is related to cancer metastasis [24, 25]. Snail is required for TGF- $\beta 1$-induced EMT $[48,49]$. Natural products, such as Jianpi Huayu Decoction, Nobiletin and Resveratrol, could inhibit EMT by inhibiting TGF- $\beta 1 /$ Smad signaling and Snail [50-52]. Our results showed that Smad3 phosphorylation and Snail expression were increased in Bel-7402 cells by TGF- $\beta 1$, suggesting that EMT induced by TGF- $\beta 1$ was associated with Smad3 and Snail. YGJDSJ could inhibit TGF- $\beta 1$-induced EMT, and decrease Smad3 phosphorylation and Snail expression, suggesting that Smad3 and Snail were involved in the effect of YGJDSJ on EMT.

EMT causes cancer cells to acquire mesenchymal phenotype, enhance their adhesion, migration and invasion capacities, thus promoting tumor metastasis $[27-29$, 53]. The present study showed that TGF- $\beta 1$-induced EMT could enhance cell adhesion, migration and invasion of Bel-7402 cells. YGJDSJ inhibited cell adhesion, migration and invasion induced by TGF- $\beta 1$, suggesting that YGJDSJ can inhibit metastatic potential of Bel-7402 cells by inhibiting EMT.

\section{Conclusions}

In conclusion, YGJDSJ inhibits TGF- $\beta 1$-induced EMT and cell adhesion, migration and invasion in Bel-7402 cells, which is related to down-regulation of Smad3 phosphorylation and Snail expression. The present study provides a new basis for the application of YGJDSJ for the prevention and treatment of HCC metastasis, which is worthy of further study.

\begin{abstract}
Abbreviations
ANOVA: Analysis of variance; CBTCCCAS: The Cell Bank of Type Culture Collection of Chinese Academy of Sciences; DMEM: Dulbecco's modified Eagle's medium; ECL: Enhanced chemiluminence; EMT: Epithelial-

mesenchymal transition; FBS: Fetal bovine serum; GAPDH: Glyceraldehyde-3phosphate dehydrogenase; HCC: Hepatocellular carcinoma; PBS: Phosphatebuffered saline; SDS-PAGE: Sodium dodecyl sulfate-polyacrylamide gel electrophoresis; TGF- $\beta 1$ : Transforming growth factor- $\beta 1$; YGJDSJ: Yanggan Jiedu Sanjie herbal formula
\end{abstract}

\section{Acknowledgements}

Not applicable.

Ethic approval and consent to participate Not Applicable.

\section{Funding}

This study was supported by Program from Science \& Technology Commission of Shanghai Municipality (09JC1413600 and 16401902500).

\section{Availability of data and materials}

The datasets used and/or analyzed during the current study available from the corresponding author on reasonable request.

\section{Authors' contributions}

$\mathrm{BH}$ conceived and designed the study. BH, HMA, XY, JLZ, XWH and ML carried out the experiment. HMA analyzed the data. BH drafted and revised the manuscript. All authors read and approved the final manuscript.

\section{Consent for publication}

Not applicable.

\section{Competing interests}

The authors declare that they have no competing interests.

\section{Publisher's Note}

Springer Nature remains neutral with regard to jurisdictional claims in published maps and institutional affiliations.

\section{Author details}

${ }^{1}$ Institute of Traditional Chinese Medicine in Oncology, Department of Oncology, Longhua Hospital, Shanghai University of Traditional Chinese 
Medicine, Shanghai 200032, People's Republic of China. ${ }^{2}$ Department of Science \& Technology, Longhua Hospital, Shanghai University of Traditional Chinese Medicine, Shanghai 200032, People's Republic of China.

Received: 29 May 2018 Accepted: 10 March 2019

Published online: 15 March 2019

\section{References}

1. Bray F, Ferlay J, Soerjomataram I, Siegel RL, Torre LA, Jemal A. Global cancer statistics 2018: GLOBOCAN estimates of incidence and mortality worldwide for 36 cancers in 185 countries. CA Cancer J Clin. 2018 Sep 12. https://doi. org/10.3322/caac.21492.

2. Hartke J, Johnson M, Ghabril M. The diagnosis and treatment of hepatocellular carcinoma. Semin Diagn Pathol. 2017;34(2):153-9.

3. Testino G, Leone S, Patussi V, Scafato E, Borro P. Hepatocellular carcinoma: diagnosis and proposal of treatment. Minerva Med. 2016;107(6):413-26.

4. Uchino K, Tateishi R, Shiina S, Kanda M, Masuzaki R, Kondo Y, et al. Hepatocellular carcinoma with extrahepatic metastasis: clinical features and prognostic factors. Cancer. 2011;117(19):4475-83.

5. Natsuizaka M, Omura T, Akaike T, Kuwata Y, Yamazaki K, Sato T, et al. Clinical features of hepatocellular carcinoma with extrahepatic metastases. J Gastroenterol Hepatol. 2005;20(11):1781-7.

6. Desai JR, Ochoa S, Prins PA, He AR. Systemic therapy for advanced hepatocellular carcinoma: an update. J Gastrointest Oncol. 2017;8(2):243-55.

7. Dutta R, Mahato RI. Recent advances in hepatocellular carcinoma therapy. Pharmacol Ther. 2017:173:106-17.

8. Reichl P, Haider C, Grubinger M, Mikulits W. TGF- $\beta$ in epithelial to mesenchymal transition and metastasis of liver carcinoma. Curr Pharm Des. 2012;18(27):4135-47.

9. Giannelli G, Koudelkova P, Dituri F, Mikulits W. Role of epithelial to mesenchymal transition in hepatocellular carcinoma. J Hepatol. 2016;65(4): 798-808.

10. Cao J, Liu J, Long J, Fu J, Huang L, Li J, et al. microRNA-23b suppresses epithelial-mesenchymal transition (EMT) and metastasis in hepatocellular carcinoma via targeting Pyk2. Biomed Pharmacother. 2017:89:642-50.

11. Qin CD, Ma DN, Ren ZG, Zhu XD, Wang CH, Wang YC, et al. Astragaloside IV inhibits metastasis in hepatoma cells through the suppression of epithelial-

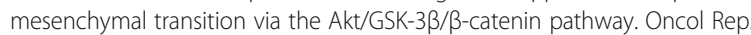
2017;37(3):1725-35.

12. Hu B, Zhang T, An HM, Zheng JL, Yan X, Huang XW. Herbal formula YGJDSJ inhibits anchorage-independent growth and induces anoikis in hepatocellular carcinoma Bel-7402 cells. BMC Complement Altern Med. 2018;18(1):17

13. Lai YJ, Tai CJ, Wang CW, Choong CY, Lee BH, Shi YC, et al. Anti-cancer activity of Solanum nigrum (AESN) through suppression of mitochondrial function and epithelial-mesenchymal transition (EMT) in breast cancer cells. Molecules. 2016;21(5):553.

14. Shen $\mathrm{KH}$, Liao AC, Hung JH, Lee WJ, Hu KC, Lin PT, et al. a-Solanine inhibits invasion of human prostate cancer cell by suppressing epithelial-mesenchymal transition and MMPs expression. Molecules. 2014;19(8):11896-914.

15. Sun P, Sun D, Wang X. Effects of Scutellaria barbata polysaccharide on the proliferation, apoptosis and EMT of human colon cancer HT29 cells. Carbohydr Polym. 2017;167:90-6.

16. Chen PN, Yang SF, Yu CC, Lin CY, Huang SH, Chu SC, et al. Duchesnea indica extract suppresses the migration of human lung adenocarcinoma cells by inhibiting epithelial-mesenchymal transition. Environ Toxicol. 2017;2(8): 2053-63.

17. Zhu T, Li X, Luo L, Wang X, Li Z, Xie $P$, et al. Reversion of malignant phenotypes of human glioblastoma cells by $\beta$-elemene through $\beta$-cateninmediated regulation of stemness-, differentiation- and epithelial-tomesenchymal transition-related molecules. J Transl Med. 2015;13:356.

18. Yarrow JC, Perlman ZE, Westwood NJ, Mitchison TJ. A high-throughput cell migration assay using scratch wound healing, a comparison of image-based readout methods. BMC Biotechnol. 2004;4:21.

19. Liang CC, Park AY, Guan JL. In vitro scratch assay: a convenient and inexpensive method for analysis of cell migration in vitro. Nat Protoc. 2007; 2(2):329-33.

20. Hu B, An HM, Shen KP, Song HY, Deng S. Polygonum cuspidatum extract induces anoikis in hepatocarcinoma cells associated with generation of reactive oxygen species and downregulation of focal adhesion kinase. Evid Based Complement Alternat Med. 2012;2012:607675.
21. An HM, Xue YF, Shen YL, Du Q, Hu B. Sodium valproate induces cell senescence in human hepatocarcinoma cells. Molecules. 2013;18(12):14935-47.

22. Boldbaatar A, Lee $\mathrm{S}$, Han S, Jeong AL, Ka HI, Buyanravjikh S, et al. Eupatolide inhibits the TGF- $\beta 1$-induced migration of breast cancer cells via downregulation of SMAD3 phosphorylation and transcriptional repression of ALK5. Oncol Lett 2017;14(5):6031-6039.

23. Lou C, Zhang F, Yang M, Zhao J, Zeng W, Fang X, et al. Naringenin decreases invasiveness and metastasis by inhibiting TGF- $\beta$-induced epithelial to mesenchymal transition in pancreatic cancer cells. PLoS One. 2012;7(12):e50956

24. Nishioka R, Itoh S, Gui T, Gai Z, Oikawa K, Kawai M, et al. SNAlL induces epithelial-to-mesenchymal transition in a human pancreatic cancer cell line (BxPC3) and promotes distant metastasis and invasiveness in vivo. Exp Mol Pathol. 2010;89(2):149-57.

25. Wang Y, Shi J, Chai K, Ying X, Zhou BP. The role of Snail in EMT and tumorigenesis. Curr Cancer Drug Targets. 2013;13(9):963-72.

26. Niit M, Hoskin V, Carefoot E, Geletu M, Arulanandam R, Elliott B, et al. Cellcell and cell-matrix adhesion in survival and metastasis: Stat3 versus Akt. Biomol Concepts. 2015;6(5-6):383-99.

27. Xu Z, Shen MX, Ma DZ, Wang LY, Zha XL. TGF-beta1-promoted epithelial-tomesenchymal transformation and cell adhesion contribute to TGF-beta1enhanced cell migration in SMMC-7721 cells. Cell Res. 2003;13(5):343-50.

28. Gavert N, Ben-Ze'ev A. Epithelial-mesenchymal transition and the invasive potential of tumors. Trends Mol Med. 2008;14(5):199-209.

29. Ding W, You H, Dang H, LeBlanc F, Galicia V, Lu SC, et al. Epithelial-tomesenchymal transition of murine liver tumor cells promotes invasion. Hepatology. 2010;52(3):945-53.

30. Hu B, Du Q, Deng S, An HM, Pan CF, Shen KP, et al. Ligustrum lucidum Ait. Fruit extract induces apoptosis and cell senescence in human hepatocellular carcinoma cells through upregulation of p21. Oncol Rep. 2014;32(3):1037-42.

31. Dai ZJ, Wang XJ, Li ZF, Ji ZZ, Ren HT, Tang W, et al. Scutellaria barbate extract induces apoptosis of hepatoma $\mathrm{H} 22$ cells via the mitochondrial pathway involving caspase-3. World J Gastroenterol. 2008;14(48):7321-8.

32. Wang HC, Chung PJ, Wu CH, Lan KP, Yang MY, Wang CJ. Solanum nigrum L. polyphenolic extract inhibits hepatocarcinoma cell growth by inducing G2/ M phase arrest and apoptosis. J Sci Food Agric. 2011;91(1):178-85.

33. Peng B, Hu Q, Liu X, Wang L, Chang Q, Li J, et al. Duchesnea phenolic fraction inhibits in vitro and in vivo growth of cervical cancer through induction of apoptosis and cell cycle arrest. Exp Biol Med (Maywood). 2009;234(1):74-83.

34. Cheng J, Han W, Wang Z, Shao Y, Wang Y, Zhang Y, et al. Hepatocellular carcinoma growth is inhibited by Euphorbia helioscopia L. extract in nude mice xenografts. Biomed Res Int. 2015;2015:601015.

35. Wang AW, Yuan H, Sun PY, Yuan JR, Geng H. Antitumor effect of different extracts from Radix Ranunculus ternate in H22 hepatoma. Chin J New Drugs. 2006;15(12):971-4 Chinese.

36. Chen X, Tong Y, Yang F, Dai G, Ren Z, Wang B. The study on effects of Radix Ranunculus ternate saponins on the activity of human hepatocarcinoma cell line HepG2. Shandong Med J. 2013;51(10):3-5. Chinese.

37. Jiang $S$, Ling C, Li W, Jiang H, Zhi Q, Jiang M. Molecular mechanisms of anti-cancer activities of $\beta$-elemene: targeting hallmarks of cancer. Anti Cancer Agents Med Chem. 2016;16(11):1426-34.

38. Kasi PD, Tamilselvam R, Skalicka-Woźniak K, Nabavi SF, Daglia M, Bishayee A, et al. Molecular targets of curcumin for cancer therapy: an updated review. Tumour Biol. 2016:37(10):13017-28.

39. Du Q, Hu B, An HM, Shen KP, Xu L, Deng S, et al. Synergistic anticancer effects of curcumin and resveratrol in Hepa1-6 hepatocellular carcinoma cells. Oncol Rep. 2013;29(5):1851-8.

40. Peng W, Qin R, Li X, Zhou H. Botany, phytochemistry, pharmacology, and potential application of Polygonum cuspidatum sieb.Et Zucc.: a review. J Ethnopharmacol. 2013;148(3):729-45.

41. Zhang X, Li Y, Zhang Y, Song J, Wang Q. Zheng L,et al. Beta-elemene blocks epithelial-mesenchymal transition in human breast cancer cell line MCF-7 through Smad3-mediated down-regulation of nuclear transcription factors. PLoS One. 2013;8(3):e58719.

42. Wang $\mathrm{H}$, Zhang $\mathrm{H}$, Tang $\mathrm{L}$, Chen $\mathrm{H}$, Wu C, Zhao $\mathrm{M}$, et al. Resveratrol inhibits TGF- $\beta 1$-induced epithelial-to-mesenchymal transition and suppresses lung cancer invasion and metastasis. Toxicology. 2013:303:139-46.

43. Baribeau S, Chaudhry P, Parent S, Asselin É. Resveratrol inhibits cisplatininduced epithelial-to-mesenchymal transition in ovarian cancer cell lines. PLoS One. 2014;9(1):e86987. 
44. Sun Y, Wang H, Liu M, Lin F, Hua J. Resveratrol abrogates the effects of hypoxia on cell proliferation, invasion and EMT in osteosarcoma cells through downregulation of the HIF-1a protein. Mol Med Rep. 2015;11(3):1975-81.

45. Zhou SJ, Liu FY, Zhang AH, Liang HF, Wang Y, Ma R, et al. MicroRNA-199b$5 p$ attenuates TGF- $\beta 1$-induced epithelial-mesenchymal transition in hepatocellular carcinoma. Br J Cancer. 2017;117(2):233-44.

46. Macias MJ, Martin-Malpartida P, Massagué J. Structural determinants of Smad function in TGF- $\beta$ signaling. Trends Biochem Sci. 2015;40(6):296-308.

47. Aomatsu K, Arao T, Sugioka K, Matsumoto K, Tamura D, Kudo K, et al. TGF- $\beta$ induces sustained upregulation of SNAI1 and SNAI2 through Smad and non-Smad pathways in a human corneal epithelial cell line. Invest Ophthalmol Vis Sci. 2011;52(5):2437-43.

48. Cho HJ, Baek KE, Saika S, Jeong MJ, Yoo J. Snail is required for transforming growth factor-beta-induced epithelial-mesenchymal transition by activating Pl3 kinase/Akt signal pathway. Biochem Biophys Res Commun. 2007;353(2):337-43.

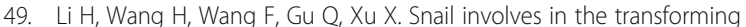
growth factor $\beta 1$-mediated epithelial-mesenchymal transition of retinal pigment epithelial cells. PLoS One. 2011;6(8):e23322.

50. Zhong C, Zhang YF, Huang JH, Wang ZY, Chen QY, Su LT, et al. The Chinese medicine, Jianpi Huayu decoction, inhibits the epithelial mesenchymal transition via the regulation of the Smad3/Smad7 cascade. Am J Transl Res. 2017;9(6):2694-711.

51. Ji Q, Liu X, Han Z, Zhou L, Sui H, Yan L, et al. Resveratrol suppresses epithelial-to-mesenchymal transition in colorectal cancer through TGF- $\beta 1 /$ Smads signaling pathway mediated Snail/E-cadherin expression. BMC Cancer. 2015;15:97.

52. Da C, Liu Y, Zhan Y, Liu K, Wang R. Nobiletin inhibits epithelialmesenchymal transition of human non-small cell lung cancer cells by antagonizing the TGF- $\beta 1 /$ Smad3 signaling pathway. Oncol Rep. 2016;35(5): 2767-74.

53. Yeung KT, Yang J. Epithelial-mesenchymal transition in tumor metastasis. Mol Oncol. 2017;11(1):28-39.

Ready to submit your research? Choose BMC and benefit from:

- fast, convenient online submission

- thorough peer review by experienced researchers in your field

- rapid publication on acceptance

- support for research data, including large and complex data types

- gold Open Access which fosters wider collaboration and increased citations

- maximum visibility for your research: over $100 \mathrm{M}$ website views per year

At $\mathrm{BMC}$, research is always in progress.

Learn more biomedcentral.com/submissions 